\title{
Analysis of the Resistance to Bending of Gypsum with Added Graphene
}

\author{
Luis M. Serna Jara *, José A. Flores Yepes and Joaquín J. Pastor Pérez
}

Citation: Jara, L.M.S.; Yepes, J.A.F.; Pérez, J.J.P. Analysis of the Resistance to Bending of Gypsum with Added Graphene. Coatings 2021, 11, 650. https://doi.org/10.3390/ coatings11060650

Academic Editor: Andrea Nobili

Received: 11 May 2021

Accepted: 27 May 2021

Published: 28 May 2021

Publisher's Note: MDPI stays neutral with regard to jurisdictional claims in published maps and institutional affiliations.

Copyright: (c) 2021 by the authors. Licensee MDPI, Basel, Switzerland. This article is an open access article distributed under the terms and conditions of the Creative Commons Attribution (CC BY) license (https:// creativecommons.org/licenses/by/ $4.0 /)$.
Department of Engeneering, Miguel Hernandez University, 03312 Orihuela, Spain; ja.flores@umh.es (J.A.F.Y.); jjpastor@umh.es (J.J.P.P.)

* Correspondence: luis.serna@goumh.umh.es

\begin{abstract}
Gypsum-based interior coatings are used due to their excellent fire resistance and thermal and acoustic properties. In recent decades, the development of these calcium sulfate-based coatings has been linked with the use of new additives that allow the setting times and the water content of the mix to be controlled and offer the possibility of adding different aggregates to the mortar, which further improve its resistance properties. In this article, significant results are presented that compare the flexural strength of mortars formed using added construction plaster with different percentages of graphene powder.
\end{abstract}

Keywords: gypsum; graphene; resistance; bending; additives

\section{Introduction}

Gypsum is a natural stone, called aljez or gypsum stone, composed mainly of calcium sulfate crystallized with two water molecules $\left(\mathrm{CaSO}_{4} \cdot 2 \mathrm{H}_{2} \mathrm{O}\right)$, called calcium sulfate dihydrate or dihydrate. In the dehydration of the stone, the rock should not be subjected to temperatures exceeding $180^{\circ} \mathrm{C}$. Th powdered product obtained from the calcination and grinding of the stone described above is composed of several anhydrous or semi-hydrates of the compound, $\mathrm{CaSO}_{4} \cdot 2 \mathrm{H}_{2} \mathrm{O}$, which, when mixed with water, has the ability to harden through a physical-chemical process called setting.

In this developed and globalized world, which has witnessed the development of and advances in many new technological, the research and development of new materials are continuous, mainly existing materials are evolving with the aim of improving their mechanical properties, optimizing their production, or achieving an economic improvement.

The case presented in this work is an analysis of the mechanical properties of calcium sulfate added to a material, such as graphene.

Since graphene was discovered by physicists. Geim and Novoselov, researchers at the University of Manchester, who won the Nobel Prize for their pioneering experiments on the two-dimensional material graphene, have had careers in different institutions, research centers, and universities in relation to the research of this material and its applications. Therefore, we aimed to study whether improvements in the mechanical properties of calcium sulfate are produced using graphene as an additive.

The aim of these additive mortars is to improve various properties, such as workability, increased hardness, and flexural and compression resistance, to achieve an innovative material with more-suitable characteristics for applications in industry, in general, and, specifically, in construction as a material providing continuous interior cladding in buildings for industrial and residential use, as a prefabricated material, or as a substitute for ceramic brick because significantly less $\mathrm{CO}_{2}$ is emitted in its production.

Examining our current knowledge on topics related to plasters, we found many scientific studies in which different materials were incorporated into plasters to modify and improve some of their physical or mechanical properties. Some of the most outstanding are: 
- Plaster with cellulose fiber. The intergypsum fiber-gypsum panel [1] is a homogeneous mixture of gypsum plaster and cellulose fiber from recycled paper.

- Applications of cork in the field of construction, with the study of new composite materials based on cork waste and the conglomerates used most frequently in the construction of buildings such as concrete, mortar, and gypsum/plaster [2].

- Combinations of expanded polyethylene (EPS) waste conglomerates with gypsum or plaster for use in construction [3].

- Incorporation of mussel shells in plaster and mortar. The properties of the mussel shell make it a convenient material to be incorporated as an aggregate. Mussel shells, as aggregates, are a feasible option for the valuation of the material, which, in addition to eliminating the dumping of this material, helps reduce the consumption of a natural resource that is becoming increasingly scarce (Figuereo and Altagracia, 2011) [4].

This manuscript presents the results of the bending resistance of plaster mortars through the use of an additive such as graphene.

\section{Materials and Methods}

\subsection{Materials}

The materials used to conduct the test, as well as the equipment and instruments used, are described in the sections below.

\subsubsection{Water}

The mortar for this test was obtained by mixing brown plaster and graphene with water obtained directly from the drinking water supply system. Water was used in the correct amount for the purpose of the tests being undertaken. Water, in the correct amount, facilitates the setting and distribution of the mortar within the molds when preparing test specimens.

\subsubsection{Plaster}

Brown plaster (also called black plaster) was used for the tests. Its nominal properties are defined according to UNE-EN 13279-1 [5], and we used Gypsum B1 construction, as follows: Thick gypsum was formed of semihydrate $\left(\mathrm{SO}_{4} \mathrm{Ca} \cdot 1 / 2 \mathrm{H}_{2} \mathrm{O}\right)$ with more than $50 \%$ hemihydrate with the possible incorporation of setting-regulating additives. The minimum bending and compression resistances were 1 and $2 \mathrm{~N} / \mathrm{mm}^{2}$, according to European regulations.

Brown plaster is used as a binder material for partitions, in interior coatings, and as secondary construction mortar. This plaster is primarily used for economic reasons as it is a less expensive plaster compared with others of higher purity that provide better results but increase the final cost, which important in civil and industrial applications. Table 1:

The plaster that was used has the following technical specifications, as shown in

Table 1. Technical specifications of the plaster used (Source: PLACO S.A.) [6].

\begin{tabular}{cr}
\hline & Specifications of the Plaster Used \\
\hline Material & Plaster \\
\hline Commercial Name & Iberplast \\
\hline Classification (UNE-EN-13.279-1:2009) & Building plasters and gypsum-based conglomerates for the building industry \\
\hline Type & B1 (Building plaster) in accordance with the European denomination. \\
\hline Reaction to fire & $\begin{array}{c}\text { Euroclass A1 (does not contribute to fire) has less than 1\% in weight or volumen of } \\
\text { organic material, according to Directive 89/106/European Economic Community, CEE } \\
\text { relative to building materials }\end{array}$ \\
\hline
\end{tabular}


Table 1. Cont.

\begin{tabular}{|c|c|}
\hline \multicolumn{2}{|c|}{ Specifications of the Plaster Used } \\
\hline Purity Index (\%) & $>75$ \\
\hline Granulometry (mm) & $0-2$ \\
\hline Water/gypsum content $(\mathrm{L} / \mathrm{kg})$ & $1,0-1,2$ \\
\hline Shore hardness (Shore C units) & $\begin{array}{l}\geq 45 \text { (test mean value according to Annex K of the RP } 35.01 \\
\text { (Standard for B1 construction plasters)) }\end{array}$ \\
\hline Compression resistance & $>2 \mathrm{~N} / \mathrm{mm}^{2}$ \\
\hline Bending resistance & $>2 \mathrm{~N} / \mathrm{mm}^{2}$ \\
\hline
\end{tabular}

\subsubsection{Graphene}

At present, graphene is marketed under the following types [7]: (1) Graphene in sheets [8] is high-quality graphene. The production of graphene in sheets is expensive, and it is used in fields such as computers, electronics, and aeronautics where a very strong material is required. (2) Graphene powder [9] is of lower quality than graphene in sheets. Its production volume is higher and lower cost.

The technical specifications of graphene are shown in Table 2.

Table 2. Specifications of powder graphene (Source: LucasLed Smart Saving) [10].

\begin{tabular}{cc}
\hline Material & Graphene \\
Composition & Solid powder \\
Colour & Black \\
Smell & Odorless \\
Solid particles & $98 \%$ \\
Mean size of particles & $10 \mathrm{microns}$ \\
Density & $2.2 \mathrm{~g} / \mathrm{cm}^{3}$ \\
Mechanical properties & $1.060 \mathrm{GPa}$ \\
Chemical composition & $\mathrm{C}(\%): 77-87 \%, \mathrm{H}(\%): 0-1 \%, \mathrm{~N}(\%): 0-1 \% \mathrm{~S}(\%): 0 \%, \mathrm{O}(\%): 13-22 \%$ \\
\hline
\end{tabular}

The tests on gypsum specimens were conducted using a universal testing machine (Lucasled, Madrid, Spain) from the construction laboratory of the Miguel Hernández University to obtain the bending strength, modulus of elasticity, and density of the specimens.

The items used in the construction laboratory of the Miguel Hernández University included: plastic buckets for weighing the materials and mixing the plaster; an electronic scale (Flintec, Barcelona, Spain): with a tolerance of $2 \times 10^{-6}$ of the maximum weight, equivalent to a precision of $0.01 \mathrm{~g}$; steel molds for the gypsum specimens $(160 \mathrm{~mm} \times 40 \mathrm{~mm} \times 40 \mathrm{~mm})$ as per the relevant standard; and auxiliary laboratory material including pipette, spatula, grids for drying, etc.

\subsection{Methods}

As few studies have been conducted involving the addition of graphene to plaster mortar, the following laboratory methodology was used, which was developed based on the UNE-EN 13279-2 Standard [11]. A total of 27 samples in three batches of nine specimens each were prepared $(40 \mathrm{~mm} \times 40 \mathrm{~mm} \times 160 \mathrm{~mm})$ to obtain results to use as a reference when comparing the results obtained with the graphene-additive gypsum mortars. Subsequently, a total of 27 samples in three batches of nine specimens each, with the same dimensions, were produced to obtain results of the gypsum mortar with the graphene additive. For the sake of brevity, only the results corresponding to the mean values of each of the batches are presented.

The experimental methodology for the preparation of the test specimens is described below. 


\section{Determination of the Proposed Compound}

We selected the minimum water/gypsum (W/G) ratio to allow for the mixing of the product.

We fabricated the gypsum at different doses both with without additives.

\subsection{Characterization of the Prepared Composite Materials}

For the determination of the physical and mechanical properties, a series of $40 \mathrm{~mm} \times 40 \mathrm{~mm} \times 160 \mathrm{~mm}$ specimens was prepared based on the UNE-EN 13279-2 Standard [11]. Nine specimens per batch were produced in the laboratory with a controlled laboratory temperature of $23 \pm 2{ }^{\circ} \mathrm{C}$ and a relative humidity (RH) of $50 \% \pm 5 \%$ over 7 days.

\subsubsection{Mixing and Dosing of the Reference Plaster Mortar}

These graphene percentages were selected for economic reasons, since graphene is currently an expensive material, so it must be used in small quantities to control the price of the final gypsum product. As fabricated, it can be used in the coverings of buildings, gauze for traumatology, etc. For the preparation of these tests, reference samples of gypsum mortar were fabricated to serve as a basis for referencing the different samples of the graphene-additive gypsum samples produced with different proportions of constituents, as indicated in Table 3.

Table 3. Reference data on gypsum mortar samples.

\begin{tabular}{cccccc}
\hline \multicolumn{4}{c}{ Reference Plaster Mortar } \\
\hline Sample & Weight of the Sample (g) & Batch No. & Plaster (\%) & Water (\%) & P/W Ratio \\
Plaster Mortar (Reference) & 3000 & 1 & 65 & 35 & 1.86 \\
\hline
\end{tabular}

To prepare the samples, a base sample of gypsum mortar was used for each mixing or batch to serve as a reference, and we prepared three batches with nine specimens each, as shown in Table 4.

Table 4. Dosages and water/gypsum ratios of the reference sample.

\begin{tabular}{ccccccc}
\hline No. of Batches & $\begin{array}{c}\text { Weight of Plaster } \\
\text { (g)/Batch }\end{array}$ & $\begin{array}{c}\text { Weight of } \\
\text { Water (g)/Batch }\end{array}$ & $\begin{array}{c}\text { Weight of Mix } \\
\text { (g)/Batch }\end{array}$ & \% Plaster & \% Water & $\begin{array}{c}\text { No. of Specimens/ } \\
\text { Batch }\end{array}$ \\
\hline 3 & 1950 & 1050 & 3000 & 65 & 35 & 9 \\
\hline
\end{tabular}

\subsubsection{Mixing and Dosages of Gypsum Mortar with Added Graphene}

Three batches of nine specimens per batch were prepared to assess the impact of the addition of $0.05 \%, 0.08 \%$, and $0.10 \%$ graphene on the mechanical properties of the mixture obtained with the nomenclature indicated in Table 5.

Table 5. Dosages, quantity, and nomenclature of specimens with added graphene.

\begin{tabular}{cccccc}
\hline No. of Batches & $\begin{array}{c}\text { Identification of } \\
\text { Batch }\end{array}$ & Additive & Additive \% & Additive Weight (g) & $\begin{array}{c}\text { No. of } \\
\text { Specimens/Batch }\end{array}$ \\
\hline \multirow{3}{*}{3} & Batch G1 & Graphene in powder & 0.05 & 1.5 & 9 \\
& Batch G2 & Graphene in powder & 0.08 & 2.4 & 9 \\
& Batch G3 & Graphene in powder & 0.10 & 3.0 & 9 \\
\hline
\end{tabular}

For each formulation, a batch of nine standardized $40 \mathrm{~mm} \times 40 \mathrm{~mm} \times 160 \mathrm{~mm}$ prismatic specimens was produced. The test was performed according to UNE-EN 13279-2 [11] using a universal testing machine that was fitted with a 3-point bending device to obtain the bending resistance and modulus of elasticity.

The device consists of a fixed lower part with two rigid bars $100 \mathrm{~mm}$ apart on which the specimen to be tested is placed. In the upper part, an arm with free vertical movement 
ending in a tilting circular piece with a rigid bar transmits the load to the specimen. In the lower part, two metal pivots help to align the specimen and prevent it from becoming displaced during the test.

Data are collected by software that measures the applied force and the deflection every second during the test, as well as the final strength. The specimens are subject to bending stresses by applying a load of $50 \pm 10 \mathrm{~N} / \mathrm{s}$ until the specimen breaks into two pieces.

The analytical procedure for the determination of the characteristic values that are needed to classify and identify the mechanical properties is described below.

According to the above-mentioned Standard, the bending resistance is calculated once the ultimate breaking load has been recorded using:

$$
R_{\mathrm{f}}=\frac{(P \times l) / 4}{\left(b \times h^{2}\right) / 6}=\frac{3}{2} \times \frac{P \times l}{b \times h^{2}}=\frac{3}{2} \times \frac{P \times 100}{40 \times 40^{2}}
$$

where $R_{\mathrm{f}}$ is bending strength $\left(\mathrm{N} / \mathrm{mm}^{2}\right)$ and $P$ is the measured breaking load of the specimen $(\mathrm{N})$.

This is simply the general basic mechanics formula used to calculate the bending strength in $\mathrm{N} / \mathrm{mm}^{2}$ but using the specific dimensions of our specimens. Hence:

$$
R_{\mathrm{f}}=\frac{M_{\mathrm{P}}}{W_{\mathrm{S}}}
$$

where:

$$
M_{\mathrm{P}}=\frac{P \times l}{4}
$$

where $M_{\mathrm{p}}$ is the moment generated by $P$ at the centerline of the specimen, in $\mathrm{N} \cdot \mathrm{mm}$.

$$
W_{\mathrm{S}}=\frac{b \times h^{2}}{6}
$$

where $W_{\mathrm{s}}$ is the section modulus of the specimen, in $\mathrm{mm}^{3} ; l$ is the distance between test supports $(\operatorname{span})=100 \mathrm{~mm} ; b$ is the width of the specimen $=40 \mathrm{~mm} ; h$ is the depth of the specimen $=40 \mathrm{~mm}$.

The results of the bending resistance in $\mathrm{N} / \mathrm{mm}^{2}$ can be refined using the testing machine by accurately measuring the exact dimensions of each of the specimens to calculate their exact section modulus $W_{\mathrm{s}}$ in $\mathrm{mm}^{3}$, hence avoiding deviations in the results due to dimensional errors during the fabrication of the specimens.

Flexion resistance according to the UNE-EN 13279-2: 2014 Standard [11], simplifying Equation (1), and leaving the equation as a function of a single load variable, we have:

$$
R_{\mathrm{f}}=0.00234 \times P
$$

Figure 1 shows the bending test of one of the specimens of a batch.

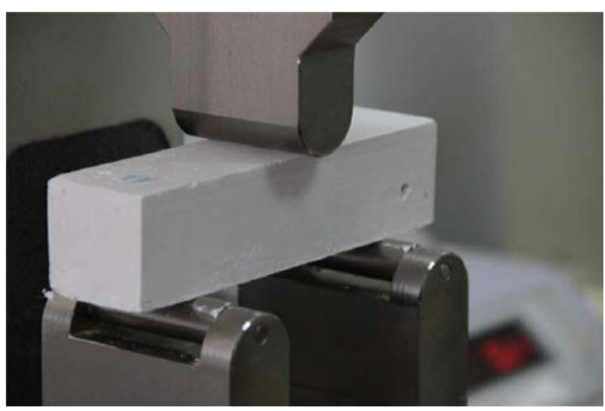

(a)

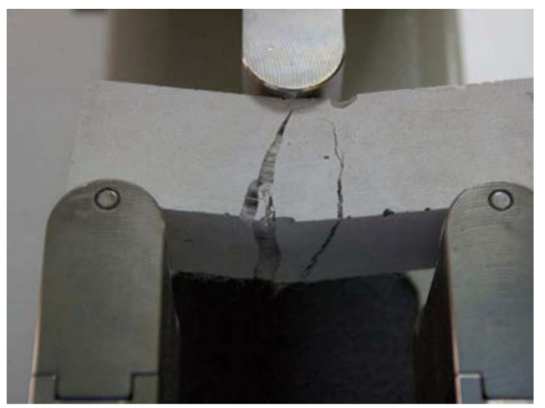

(b)

Figure 1. Flexible tested test tube, (a) is test tube to be tested, $(\mathbf{b})$ is bending specimen rupture. 


\section{Results}

The statistical analysis of the data obtained in the laboratory tests are structured here into two parts: the results of the laboratory tests, and the descriptive statistics of the data obtained.

To compare different mean values on a two-by-two basis (as there were more than two series per group), Tukey's multiple comparison test was used with a 95\% significance. To identify similarities between the different results obtained, the Tukey's and Duncan's analyses were applied, from which different conclusions may be drawn depending on their adaptation to the factors studied.

We used computer software (2016) Statistical Package for the Social Sciences SPSS to calculated the statistics [12].

The results of the flexural strength test for the reference gypsum mortar specimens $(\mathrm{G} / \mathrm{W}$ ratio $=1.86)$ are detailed in Table 6.

Table 6. Results of the flexural strength test for the reference gypsum mortar $(\mathrm{G} / \mathrm{W}$ ratio $=1.86)$.

\begin{tabular}{|c|c|c|c|c|}
\hline \multicolumn{5}{|c|}{ Flexural Strength $\left(\mathrm{N} / \mathrm{mm}^{2}\right)$} \\
\hline Batch No. & 1 & 2 & 3 & Mean value \\
\hline Strength $\left(\mathrm{N} / \mathrm{mm}^{2}\right)$ & 4.37 & 4.14 & 4.61 & 4.37 \\
\hline \multicolumn{4}{|c|}{ Mean Value } & 4.37 \\
\hline \multirow{2}{*}{\multicolumn{4}{|c|}{ Standard Deviation $+/-$}} & 0.2350 \\
\hline & & & Coefficient of Variation & 0.0538 \\
\hline
\end{tabular}

The results of the flexural strength test for the reference gypsum mortar specimens for the batches with graphene proportions of $0.05 \%, 0.08 \%$, and $0.10 \%$ are shown in Table 7 .

Table 7. Test results for the flexural strength of gypsum mortar with add graphene powder.

\begin{tabular}{|c|c|c|c|c|}
\hline \multirow[b]{2}{*}{ Batche } & \multicolumn{4}{|c|}{ Flexural Strength $\left(\mathrm{N} / \mathrm{mm}^{2}\right)$} \\
\hline & $\begin{array}{l}\text { Plaster without } \\
\text { Graphene }\end{array}$ & $\begin{array}{l}\text { Plaster and Graphene } \\
(0.05 \%)\end{array}$ & $\begin{array}{l}\text { Plaster and Graphene } \\
(0.08 \%)\end{array}$ & $\begin{array}{l}\text { Plaster and Graphene } \\
\qquad(0.10 \%)\end{array}$ \\
\hline 1 & 4.37 & 4.98 & 4.71 & 5.22 \\
\hline 2 & 4.14 & 4.34 & 4.51 & 5.52 \\
\hline 3 & 4.61 & 4.76 & 5.10 & 5.32 \\
\hline Mean value & 4.37 & 4.69 & 4.77 & 5.35 \\
\hline Standard deviation $+/-$ & 0.1305 & 0.3252 & 0.3001 & 0.1528 \\
\hline Coefficient of variation & 0.0299 & 0.0693 & 0.0629 & 0.0286 \\
\hline Maximum & 4.61 & 4.9800 & 5.1000 & 5.5200 \\
\hline Minimum & 4.14 & 4.3400 & 4.5100 & 5.2200 \\
\hline Error & - & 0.2564 & 0.0567 & 0.2539 \\
\hline Covariance & - & 0.0486 & 0.0695 & -0.0232 \\
\hline
\end{tabular}

Figure 2 shows the results obtained from the bending test for the mixture of gypsum mortar with graphene added in the proportions of $0.05 \%, 0.08 \%$, and $0.10 \%$.

The evolution of the results was observed through their third-degree polynomial curve, as well as their regression, with results above 0.85 . This means that the results obtained were representative.

When comparing the results obtained in the flexural strength test of graphene-additive gypsum mortar with the results obtained in other similar tests with different additives, we observed a considerable increase in flexural strength when graphene was added.

The comparison of our bending strength results with those of Bernal [13] on gypsum mortars with an organic-type additive with a retardant effect on the setting process and vermiculite are shown in Table 8.

Table 9 compares the above outcome with the results of the flexural strength tests reported in [14] for gypsum mortars with a polymer fiber additive. 
Table 8. Comparison of bending strength test results of gypsum mortar with added graphene powder with respect to the research results obtained by Bernal [13].

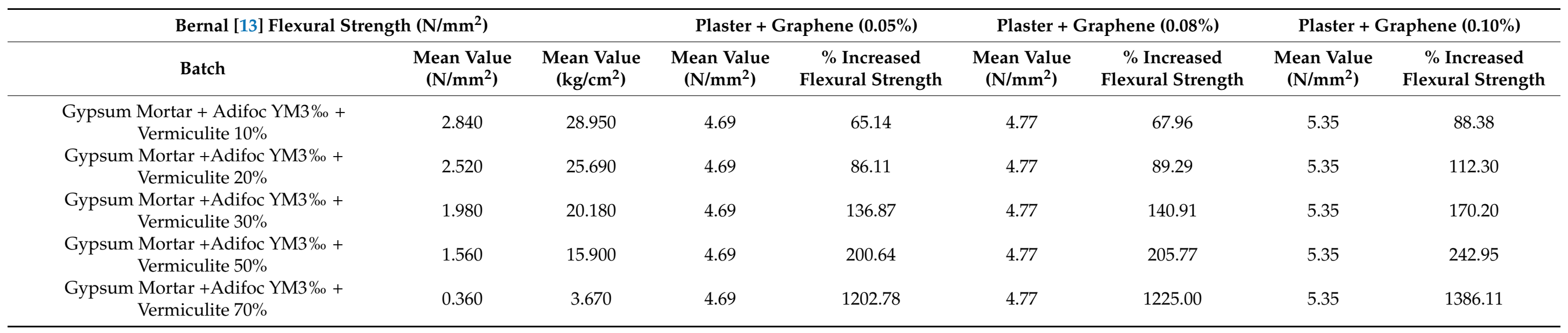

Table 9. Comparison of bending strength test results of gypsum mortar with added graphene powder with those in [14].

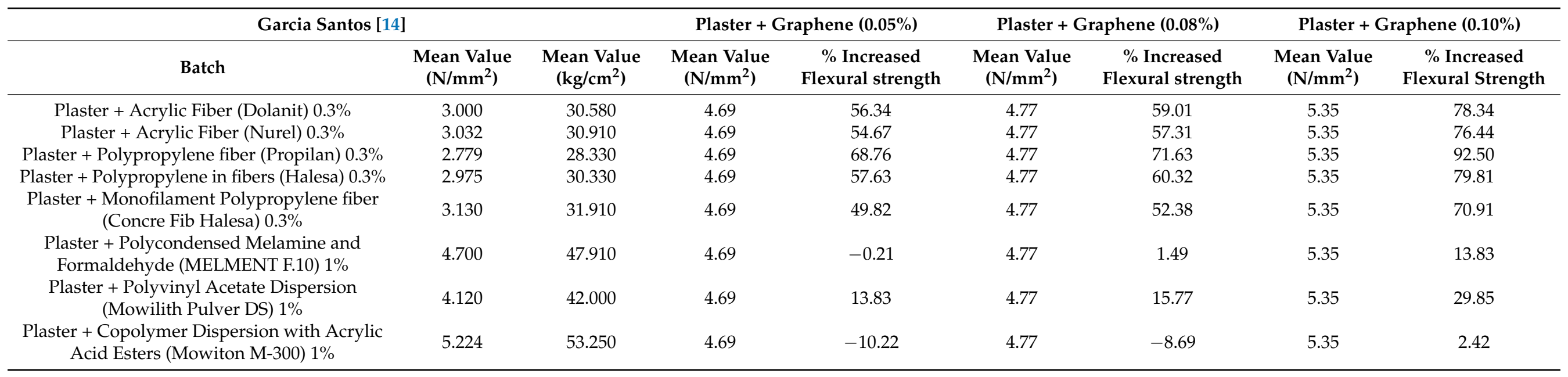




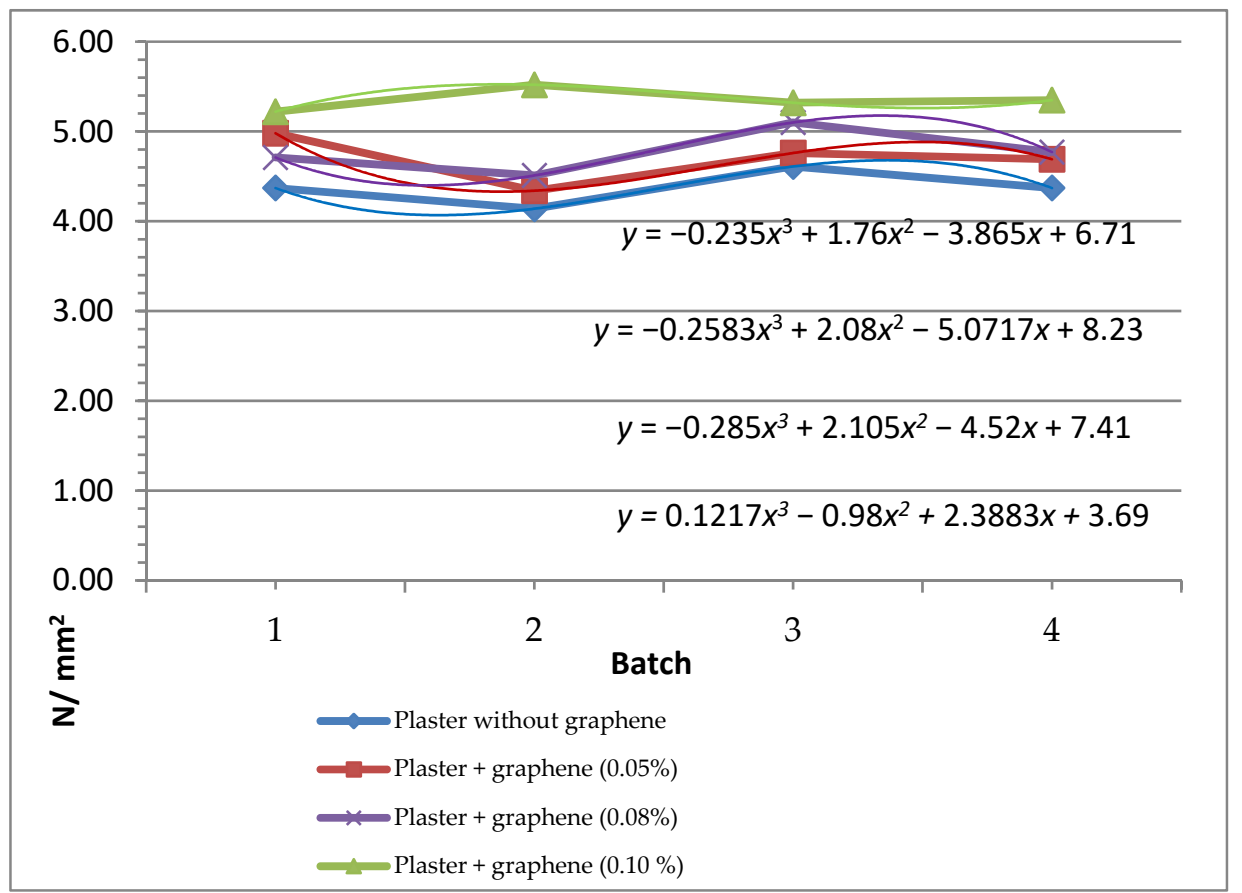

Figure 2. Flexural test results of gypsum mortar with graphene added in different proportions.

As shown in Table 10, better results were obtained by adding graphene to gypsum mortar than by adding organic- and vermiculite-type additives to gypsum mortar.

As per Table 9, the flexural strength of graphene-added mortar is higher than mortars with the addition of polyester, polypropylene, melanin, and copolymer dispersions.

Table 10 compares the results of the flexural strength to those obtained by del Río Merino [15] for plasters and plaster mortar with the addition of foaming agents, cork, glass fibers, and vermiculite.

Table 10 shows that the flexural strength of the mortar with graphene additive is higher than those of mortars with added cork and lightened plasters. 
Table 10. Comparison of flexural strength test results of gypsum mortar with graphene powder with those reported by del Río Merino [15].

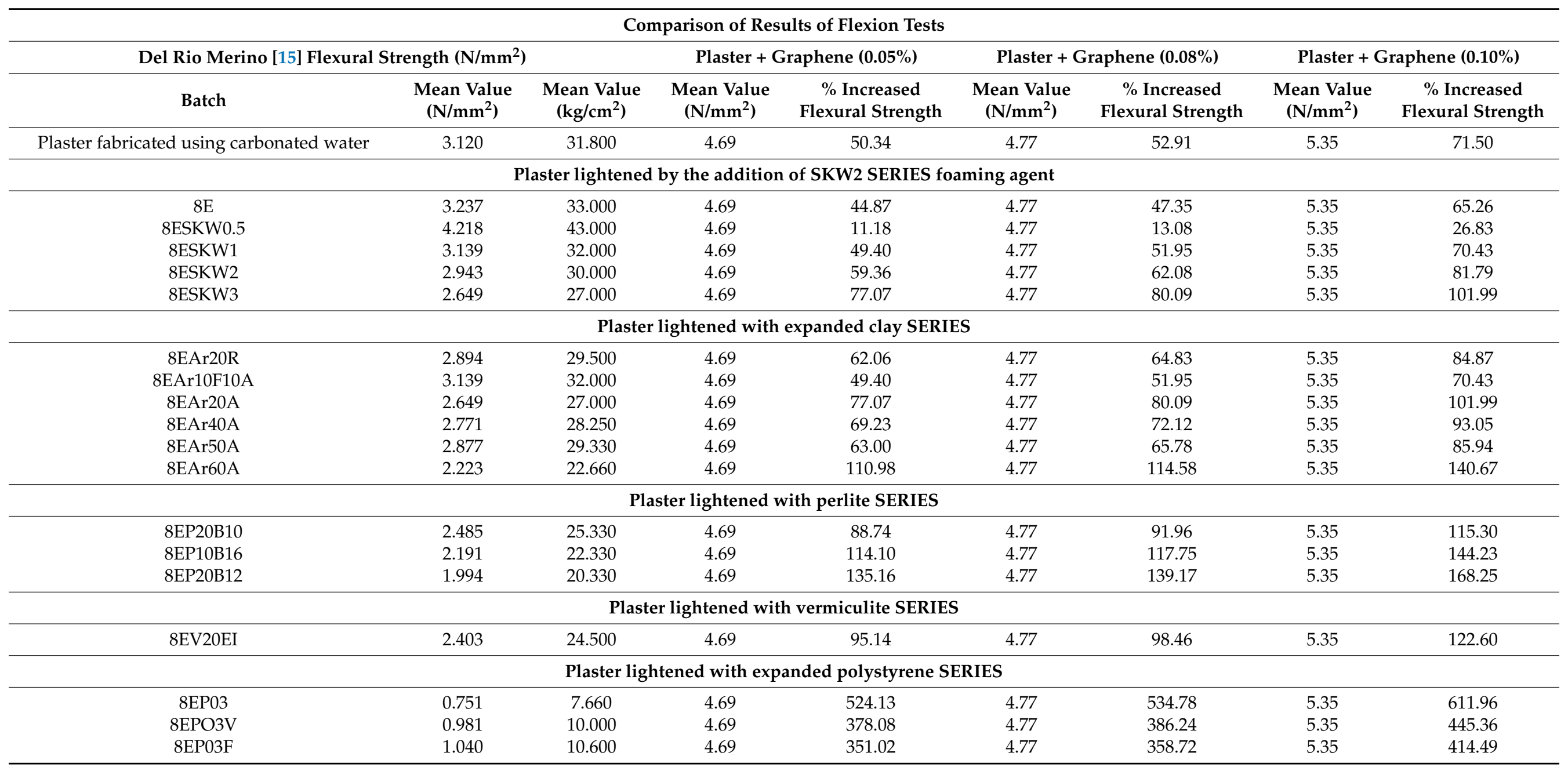




\section{Discussion}

Based on the results obtained, we found that adding graphene powder in any proportion to the reference gypsum mortar increases its flexural strength; the best result was obtained for a proportion of $0.10 \%$, which had with a maximum mean flexural strength value of $5.35 \mathrm{~N} / \mathrm{mm}^{2}$, which means that its flexural strength was increased by $0.98 \mathrm{~N} / \mathrm{mm}^{2}$, i.e., by $22.43 \%$, with respect to the reference gypsum mortar.

This increase is shown in Figure 3.

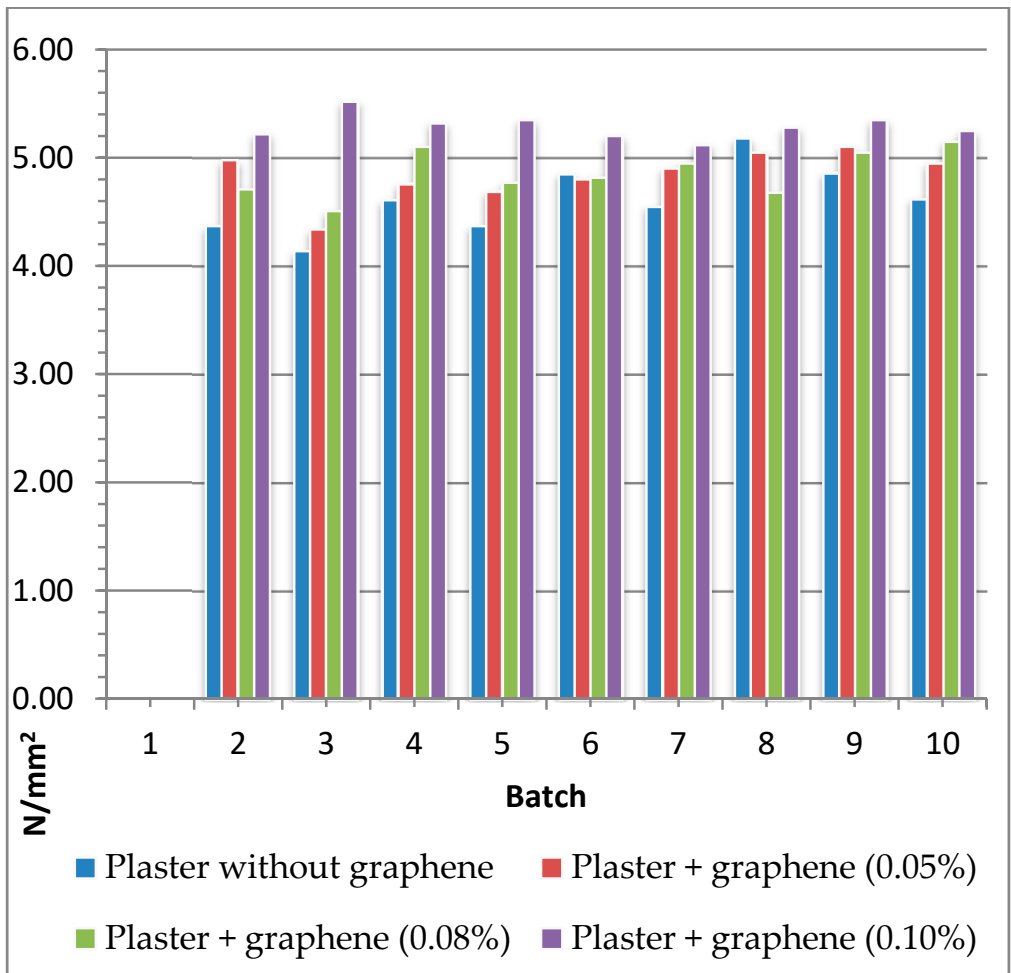

Figure 3. Bar graph of flexural strength test results of gypsum mortar with graphene added in the proportions of $0.05 \%, 0.08 \%$, and $0.10 \%$.

The results obtained when adding graphene to gypsum mortar are improved in comparison with other additives tested as shown in the values in Tables 8-10.

\section{Conclusions}

The main, general conclusions drawn from these tests are that adding graphene powder to gypsum mortar increases the mechanical properties of the gypsum mortar, leading to an increase in its bending strength. An increase in the bending strength was also obtained in comparison with plaster without any additive when graphene powder was used, with values of up to $5.35 \mathrm{~N} / \mathrm{mm}^{2}$, whereas mean values of $4.37 \mathrm{~N} / \mathrm{mm}^{2}$ were obtained in plaster without any additive, which is an increase of $22.42 \%$ in the bending strength of the gypsum mortar when $0.10 \%$ of graphene was added to the mix.

After comparing the results of the bending tests conducted with the specimens with graphene additive with those with the gypsum mortar without additives, i.e., those used as reference values, we found that when graphene powder is added to the gypsum mortar, the flexural strength increases irrespective of the proportions of graphene added to the reference gypsum plaster.

We specifically showed that the results obtained are improved compared with other tests performed with other additives used. 
These results are complementary to future Shore $C$ hardness tests; the results of the compressive strength tests of the gypsum and graphene mixture that were previously published [16] in September 2020.

Author Contributions: Investigation, L.M.S.J., J.A.F.Y., and J.J.P.P.; writing-original draft, L.M.S.J., J.A.F.Y., and J.J.P.P. All authors have read and agreed to the published version of the manuscript.

Funding: This research received no external funding.

Institutional Review Board Statement: Not applicable.

Informed Consent Statement: Not applicable.

Data Availability Statement: Not applicable.

Conflicts of Interest: The authors declare no conflict of interest.

\section{References}

1. Intergypsum, S.A. Grupo Tablicia. Available online: www.intergypsum.com (accessed on 16 May 2019).

2. Del Rio Merino, M. Nuevas Aplicaciones del Corcho en el Campo de la Edificación. In Proceedings of the III Encuentro Eurocork, Huelva, Spain, 23 October 2005.

3. González Madariaga, F.J. Caracterización de Mezclas de Residuos de Poliestireno Expandido (EPS) Conglomerados con Yeso o Escayola, su Uso en la Construcción. Ph.D. Thesis, Universidad Politécnica de Cataluña, Barcelona, Spain, 2005.

4. García Figuereo, J.A. La Incorporación de la Cáscara de Mejillones en Conglomerantes yeso, Cal y Cemento. Master's Thesis, Escuela Universitaria de Arquitectura Técnica, Universidad Politécnica de Madrid, Madrid, Spain, 2011.

5. AENOR. UNE-EN 13279-1:2009: Yesos de Construcción y Conglomerados a Base de Yeso para la Construcción. Parte 1: Definiciones y Especificaciones; UNE: Madrid, Spain, 2009.

6. Ficha Técnica yeso Iberplast. Available online: https://www.placo.es/products/yesos-manuales/iberplast (accessed on 16 May 2019).

7. Chandrasekhar, P. Conducting Polymers, Fundamentals and Applications: Including Carbon Nanotubes and Graphene; Springer: Berlin/Heidelberg, Germany; Ashwin-Ushas Corporation: Marlboro, NJ, USA, 2018.

8. Dimiev, A.M.; Siegfried, E. Graphene Oxide: Fundamentals and Applications; Wiley: Chichester, UK, 2017.

9. González, R.C.; Kharissova, O.V. Propiedades y Aplicaciones del Grafeno. Ingenierías 2008, 11, 17-23.

10. LUCASLED Smart Savings. Ficha técnica Grafeno. Available online: http:/ / www.lucasled.es/ (accessed on 16 May 2019).

11. UNE. UNE-EN 13279-2:2014 Yesos de Construcción y Conglomerantes a Base de Yeso para la Construcción. Parte 2: Métodos de Ensayo; UNE: Madrid, Spain, 2014.

12. Camacho, J. Estadística con SPSS para Windows; Alfaomega-Rama: Madrid, Spain, 2005; ISBN 978-84-7897-654-6.

13. Berná Serna, J.M. Evaluación de las Propiedades Mecánicas de los Morteros Aditivados de Yeso con Vermiculita. Ph.D. Thesis, Universidad Miguel Hernández, Alicante, Spain, 2013.

14. García Santos, A. Comportamiento mecánico de yeso reforzado con polímeros sintéticos. Inf. Construcción 1988, 40, 67-89. [CrossRef]

15. Del Rio Merino, M. Elaboración y Aplicaciones Constructivas de Paneles Prefabricados de Escayola Aligerada y Reforzada con Fibras de Vidrio e y Otros Aditivos. Ph.D. Thesis, E.T.S. Arquitectura (UPM), Granada, Spain, 1999.

16. Serna Jara, L.M.; Pastor Pérez, J.J.; Flores Yepes, J.A. Study of compressive strength of gypsum with graphene addition. Cem. Wapno Beton J. 2020, 25, 232-241. [CrossRef] 